\title{
Does Social Exclusion Cause People to Make More Donations?
}

\author{
Min-Jung $\mathrm{Oh}^{1}$, Jin Chul Jung ${ }^{2}$
}

Received: April 13, 2018. Revised: April 25, 2018. Accepted: May 5, 2018.

\begin{abstract}
The present paper study investigates the relationship between social exclusion and donation intention among specific social groups in Korea. Social exclusion refers to non-participation in social experiences by the socially disadvantaged. Data were analyzed using two sources; first was the evidence of behaviors arising from social exclusion of the university students and then socially excluded reactions of the elderly responses from the survey were compared with the first research findings. The reason of using multi-sources of data is that the outcome from the experimental design of the university student is imperative to clarify what the conclusions will be the same result with the other demographic characteristic of the elderly. The research design was three excluded elderly individuals of a self-excluded group and two other excluded groups divided such as "ignored" and "rejected" individuals to compare the differences among three groups of different sources of exclusion. The conclusion of this study is that those with high social exclusion exhibited a more negative donation intention than those with lower social exclusion, but that those who perceived themselves as self-excluded were more likely to give donations than those excluded by others, regardless of the level of their social exclusion.
\end{abstract}

Keywords: Social Exclusion, Attribution Theory, Donation Intention, Social Comparison, Social Weakness.

JEL Classification Code: E20, E21, M30, M31, M39.

\section{Introduction}

Human beings are social animals and have a basic desire to form relationships with other people and to belong to society (Baumeister \& Leary, 1995). The desire to pursue a stable and robust connection with others, as identified in Maslow's needs hierarchy theory, has been argued as the essential needs in social life (Fiske, 2004). If people perceive the unsatisfied needs or reality of not belonging to the social group or social exclusion from others, then they are likely to experience negative emotions (Buckley, Winkel, \& Leary, 2004).

The experience of exclusion causes antisocial behavior due to cognitive deficiencies that interrupt logical thought (Baumeister, DeWall, Ciarocco, \& Twenge, 2005). In other

1 First Author. Part-time lecture. Division of Business, Chosun University [Postal Address: Division of Business, Chosun University , 375 Seoseok-dong, Dong-gu, Gwangju, South Korea] E-mail: lemona13@ daum. net

2 Corresponding Author. Professor. Division of Business, Chosun University, [Postal Address: Division of Business, Chosun University, 375 Seoseok-dong, Dong-gu, Gwangju, South Korea] E-mail: jjung@chosun.ac.kr words, those who are excluded experiences adverse emotional reactions or negative behavior due to reduced cognitive information processing (Buckley et al., 2004; Warburton, Williams, \& Cairns, 2006). For example, socially excluded people are conceived as giving a more negative job evaluation to those who had offended them (Twenge, Baumeister, Tice, \& Stuke, 2001), and as allocating more spicy sauce to those who they thought disliked spicy food (Warburton et al., 2006).

So far, very little has been done in theoretically clarified for the concept of social exclusion. However, previous research has defined it as when an individual's participation is psychologically or socially constrained. For example, people are sometimes discriminated or excluded in the organization because of their social background (e.g., gender or age), and defined as "socially disadvantaged" (Lee, Jin, \& Byun, 2000).

According to 2015 National Statistical Office data, socially disadvantaged groups include women, the elderly, children, and the disabled. In Korea, where a significant portion of society is aging, and the birth rate continues to drop, the growing elderly population has become a concern. The aging rate was $13.8 \%$ in 2017 , and researchers estimated that there would be approximately $20 \%$ or more in Korea 
over 65 years old by 2026 (Statistics Korea, 2017). An additional increase in the numbers of socially disadvantaged individuals should not be ignored, mainly as these individuals are susceptible to the social exclusion that can lead to other social problems such as aggression and antisocial behavior (Twenge et al., 2001).

However, the social exclusion does not always lead to aggressive behavior (Baumeister et al., 2005; Buckley et al., 2004; Warburton et al., 2006; Williams et al., 2000). And previous studies have suggested a positive aspect of prosocial behavior, such as helping behavior, cooperative behavior, and seeking to maintain friendly interpersonal relationships (Maner, DeWall, Baumeister, \& Schaller, 2007; Mizutani, 2016; Twenge et al., 2001). Furthermore, evidence suggests that exclusion reinforce the affiliative and prosocial behavior. Other research also confirmed this proposition and argument that socially excluded people tend to express more interest in meeting new people through student-connected service and willing to more contact with others (Maner et al., 2007). In consumer behavior area, social exclusion increased spending that promoted affiliation (Mead, Baumeister, Stillman, Rawn, \& Vohs, 2011) and increased preferences for nostalgic products that helped individuals reconnect with people from their past (Loveland, Smeesters, \& Mandel, 2010). Table 1 summarizes the contradictory results of social exclusion research.

Table 1. Results of research on social exclusion.

\begin{tabular}{|c|c|c|c|}
\hline \multicolumn{2}{|c|}{ Negative Results } & \multicolumn{2}{|c|}{ Positive Results } \\
\hline researcher & $\begin{array}{l}\text { main } \\
\text { argument }\end{array}$ & researcher & main argument \\
\hline $\begin{array}{l}\text { Twenge, } \\
\text { Baumeister, } \\
\text { Tice, \& } \\
\text { Stuke } \\
(2001)\end{array}$ & $\begin{array}{l}\text { socially } \\
\text { excluded } \\
\text { people have } \\
\text { been } \\
\text { observed as } \\
\text { giving a more } \\
\text { negative job } \\
\text { evaluation to } \\
\text { those who } \\
\text { had offended } \\
\text { them }\end{array}$ & $\begin{array}{l}\text { Pickett, } \\
\text { Gardner, \& } \\
\text { Knowles } \\
(2004)\end{array}$ & $\begin{array}{l}\text { excluded } \\
\text { people became } \\
\text { more socially } \\
\text { attentive }\end{array}$ \\
\hline $\begin{array}{l}\text { Buckley, } \\
\text { Winkel, \& } \\
\text { Leary } \\
(2004)\end{array}$ & $\begin{array}{l}\text { socially } \\
\text { excluded } \\
\text { people likely } \\
\text { to experience } \\
\text { negative } \\
\text { emotions }\end{array}$ & $\begin{array}{l}\text { Maner, } \\
\text { DeWall, } \\
\text { Baumeister, } \\
\text { \& Schaller } \\
(2007)\end{array}$ & $\begin{array}{l}\text { excluded } \\
\text { people } \\
\text { expressed } \\
\text { greater interest } \\
\text { in meeting new } \\
\text { people through } \\
\text { a student } \\
\text { connection } \\
\text { service and an } \\
\text { increased } \\
\text { desire to work } \\
\text { with others }\end{array}$ \\
\hline
\end{tabular}

\begin{tabular}{|c|c|c|c|}
\hline $\begin{array}{l}\text { Baumeister, } \\
\text { DeWall, } \\
\text { Ciarocco, \& } \\
\text { Twenge } \\
(2005)\end{array}$ & $\begin{array}{l}\text { The } \\
\text { experience of } \\
\text { exclusion } \\
\text { causes } \\
\text { antisocial } \\
\text { behavior }\end{array}$ & $\begin{array}{l}\text { Lakin, } \\
\text { Chartrand, \& } \\
\text { Arkin (2008) }\end{array}$ & $\begin{array}{l}\text { excluded } \\
\text { people } \\
\text { engaged in } \\
\text { nonconscious } \\
\text { behavioral } \\
\text { mimicry }\end{array}$ \\
\hline $\begin{array}{l}\text { Buckley et } \\
\text { al. (2004), } \\
\text { Warburton, } \\
\text { Williams, \& } \\
\text { Cairns } \\
(2006)\end{array}$ & $\begin{array}{l}\text { those who } \\
\text { are excluded } \\
\text { experience } \\
\text { negative } \\
\text { emotional } \\
\text { reactions or } \\
\text { negative } \\
\text { behavior due } \\
\text { to reduced } \\
\text { cognitive } \\
\text { information } \\
\text { processing }\end{array}$ & $\begin{array}{l}\text { Mead, } \\
\text { Baumeister, } \\
\text { Stillman, } \\
\text { Rawn, \& } \\
\text { Vohs (2011) }\end{array}$ & $\begin{array}{l}\text { social } \\
\text { exclusion } \\
\text { increased } \\
\text { spending that } \\
\text { promoted } \\
\text { affiliation }\end{array}$ \\
\hline
\end{tabular}

Thus, social exclusion may incur several effects, many of which differ significantly in each different viewpoint. One explanation, explored in this research is that diverse types of social exclusion produce different outcomes. In particular, according to Deci and Ryan's (2000) theory of selfdetermination, the level of individual motivation is determined by the ability to act for oneself. Specifically, when autonomy, competence, and relationships are secured, the level of involvement is higher, and the satisfaction level is higher. In other words, if someone can choose by oneself, it can reinforce the autonomy and competence. Based on this theoretical argument, new logic can be possible of which self-exclusion may provide the different psychological mechanism with other-exclusion. Therefore, it is important to note that different outcomes may relate to the type of social exclusion individuals are experiencing (Lee \& Shrum, 2011; Molden, Lucas, Gardner, Dean, \& Knowles, 2009; Oh \& Whang, 2014).

A second implication is that previous research on social exclusion has been limited through a lack of comprehensive scenario information considering self-exclusion; this study was developed to provide additional survey data. It examined the relationship between social exclusion and donation, focusing on socially underprivileged students within a particular scenario and then, in a second specific study involving a survey, the information from the first specific study was compared with information derived from the attitudes of a particular socially disadvantaged group, namely the elderly, to the making of donations.

Overall, this study consisted of two investigations. First, we classified undergraduates as a socially excluded group and used a scenario experimental design method in which donation was measured as a dependent variable (Study 1). Second, we examined the donation intentions of elderly 
persons experiencing social exclusion and analyzed their donation intentions using attribution theory (Study 2).

\section{Theoretical Background}

\subsection{Social Comparison Theories}

The semantic research of the comparison theory (Festinger, 1954; Gibbones \& Buunk, 1999; Han, Cho, \& Yang, 2014) suggests that people are more apt to the evaluate their attitudes and behavior to compare with others in the socially weak situation. The theory is a reference to the following equity theory (Adams, 1963), and social learning theory (Bandura, 1977), which argued that the people in the uncertain situation are more motivated by others across different social context. If there is no objective basis for evaluating themselves, an individual will select someone similar to them and compare themselves to that person. Such subjective perception is a relative evaluation rather than an objective judgment.

Social comparison theory emphasizes the importance of people perceiving that they are treated as fairly as others, and that personal judgments about what is fair or unfair are derived from subjective comparison with others. In the language of social comparison theory, then, social exclusion is determined as a self-perception that one is not being treated equitably in an economic, political, or social sense. If an individual compares himself/herself to others and finds that being not treated with similar inclusion level, they will make a subjective judgment that they are socially isolated.

\subsubsection{Social exclusion and stigma}

Shim (2004) defines social exclusion as a dynamic process that liberates excluded individuals from the mainstream order of society by depriving them of political, economic, social, and cultural rights necessary for normal life in that society. Lee (2009) suggests that the expanding concepts of economically based social exclusion are a little of related to past economic deficits of poverty, but rather to health, housing, education, and the attendant constraints of social participation in social-political activities.

Although social exclusion continues to be a much discussed and debated topic, scholars have not arrived at a single clear definition of the subject (Lee, 2009; Levitas, 2006; Moon, 2010). Moreover, research on the psychological, emotional, and social aspects of socially excluded people is lacking (Levitas, 2006). A related matter in social psychology is the concept of stigma, which refers to negative perceptions and behaviors toward individuals considered to be different or to have undesirable attributes. Stigma undermines social identity and damages the ability of the stigmatized individual to maintain self-acceptance and social-acceptance (English, 1977; Goffman, 1963; Song, Lee, Hwang, \& Lee, 2015).

The concept of stigma largely derives from illness, rather than from deviant or inappropriate behavior. For example, individuals with intellectual and physical disabilities may be stigmatized (Piner \& Kahle, 1984), and therefore experience restricted access to housing, education, and job opportunities, all of which can have detrimental effects on health. Stigma results in emotional disturbances (i.e., depression, anxiety, and negative self-esteem), and then separates individuals from society (Link \& Phelan, 2001). It is an argument that stigmatized individuals do not experience social exclusion by others but rather by themselves. Therefore, social exclusion can be distinguished from self-excluded and other-excluded.

\subsubsection{Social weakness}

Over $30 \%$ of the Korean population is a socially vulnerable who discriminated against and alienated from majorities. Further, the proportion of socially disadvantaged individuals in the country is growing trends in which the number of socially weak individuals will increase. In particular, the elderly often is being socially excluded even though they have economical capacity during their social life such as community activities and social networks (Lee, 2009). Among these, economic poverty (Choi \& Ryu, 2003; Kim, 2007) and the isolation of social networks (Grenier \& Guberman, 2009) have been identified in many studies as particularly significant issues.

According to social network theory, which links social exclusion and the conceptualization of social weak with networking, the higher the economic status, the larger the social network associated with that person. In addition, individual's social network becomes a social resource, and this can be associated with economic status. Thus, the lower the economic status, the lower the social network (social resources) owned by the individual - eventually such individuals are excluded from society.

\section{Research Hypothesis}

\subsection{Social Exclusion and Donation}

Lee and Shrum (2011) classify social exclusion as involving being ignored or rejected, and identify different consumption patterns depending on the types of social 
exclusion experienced by an individual. Being ignored and being rejected differ in several respects. Being ignored is more implicit and indirect, whereas being rejected is more explicit and direct. In some circumstances, people receive explicit reaction concerning their low standing within a relation or group and are actively rejected. In other circumstances, people receive implicit feedback of their lack of social relationship and are passively ignored ( Lee \& Shrum, 2011)

However, this study examined both social exclusion by others (rejected vs. ignored) as well as a voluntary exclusion by self-will. According to theory of self-determinism, motivation level is determined by the ability to act for oneself (Deci \& Ryan, 2000). Specifically, when autonomy, competence, and relationship are secured, the level of involvement is higher and the satisfaction level is higher, emphasizing the positive aspects of human autonomous action.

An earlier study by Oh and Hwang (2014) classified purchase intentions in relation to Fair Trade products into those occurring for individuals who experienced selfexclusion and for those who experienced other-exclusion. For study 1 here, both self-exclusion and other-exclusion were considered together, and the following hypotheses were proposed:

$<\mathrm{H} 1>$ Social exclusion will affect donation intentions and will be varied based on the social exclusion types.

$<\mathrm{H}$ 1a $>$ Social exclusion types (self vs. other), (rejected vs. ignored) will different effects on donation intentions.

$<\mathrm{H} 1 \mathrm{~b}>$ Among the social exclusion types, self-exclusion will result in higher donation intentions than otherexclusion (rejected vs. ignored).

\subsection{Study 1}

\subsubsection{Research purpose and methods}

The purpose of Study 1 was to confirm whether diverse types of consumption patterns develop, based on the type of social exclusion experienced by an individual. Social exclusion has been divided into self-exclusion and otherexclusion categories, and other-exclusion has been further subdivided into "ignored" and "rejected" subcategories. People identified as falling into the category of otherexclusion can include those rejected from society for no apparent reason, whereas those ignored by society include those unwillingly excluded for a specific reason (Lee \& Shrum, 2011). This empirical research used 120 South Korean undergraduate students for experimental design, in which there were two groups divided: self-exclusion and other-exclusion.

The experiment groups of respondents were randomly assigned into two groups and be instructed to read the assigned scenario and then completed the questionnaire. Excluding the not-completed and ineligible data, the researchers used the 96 samples for final analysis. We randomly assigned the 32 samples to each three groups. The demographic characteristics of the respondents were $61.5 \%$ for males (59), and $36.5 \%$ for females (35), and 2 respondents did not respond. The average age was 21.89 .

Based on their prior donation experience, participants had to select from the responses "actively participate in donations," "consider it positive to donate," and "donate at a small cost." These questionnaire items were asked using a 7-point Likert scale $(\alpha=.916)$. A t-test was conducted to confirm whether the manipulation of the situation examining social exclusion was properly performed (Mself $=4.50$ vs Mother=2.08, $t=5.371, p<.001$ ). The higher the mean value, the more self-exclusion is identified. And the t-test was conducted to confirm whether the scenario manipulation of neglected and rejected was successful in the exclusion process(Mignored=5.08 vs Mrejected=2.73, $t=8.648$, $p<.001)$. Therefore, it was confirmed that the three types of manipulation were properly performed.

\subsubsection{Results}

Univariate analysis revealed that the group that perceived self-exclusion showed a higher donation intention than the group that perceived other-exclusion (ignored vs. rejected), as shown in Figure 1. Those who perceived self-exclusion (Mself=4.44, SD=1.26) were more likely to purchase than those who were ignored (Mignored=3.75, SD=0.92) or were rejected (Mrejected=3.93, $S D=1.12 ; F(1,91)=3.364, p<.05)$.

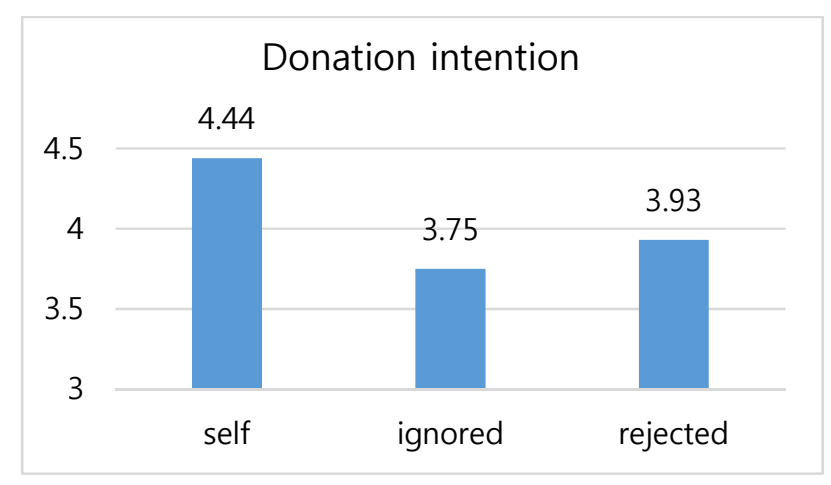

Figure 1. Analysis of donation intention with types of social exclusion 
In other words, social exclusion influenced consumers' consumption patterns, and it can be confirmed that the group who perceived self-exclusion showed a more positive consumption pattern than the group who perceived otherexclusion. Therefore, it was confirmed that $\mathrm{H}_{1}$ and $\mathrm{H}_{1 \mathrm{a}}$ were supported.

\subsection{Study 2}

\subsubsection{Moderating effects of attribution}

Attribution is a psychological explanation for why something happened, why it happened to others, or why we ourselves made a certain decision(Choi, 2016). The process of attribution occurs within a degree of psychological conflict and discomfort due to the inconsistency of expectations when individuals experience negative feedback rather than positive feedback, they make causal inferences more frequently, and these results affect their behavior (Folkes, 1988; Oliver, 1997; Weiner, 1980). Attribution theory, then, attempts to infer the reasons for behavior. In Weiner's (1980) seminal study on the subject, he classified the causes of behavior into three categories, among which, loci of causality and controllability were analyzed for this study. We attempted to confirm whether the donation is influenced by these two causal attribution categories. In general, people will seek to explain behavior if they either experience results that are in opposition to their expected results or find the results unsatisfactory. Considering that people typically do not predict that they will be excluded from society, and usually find the experience of exclusion unwelcome, it follows that if they are excluded, they will have a strong motivation to find out know why they have been excluded.

Lee and Shrum (2011) have suggested that people who experience social exclusion behave differently depending on how they reason about it. For example, when they feel threatened in their desire for a sense of efficacy and to have a meaningful presence, they tend to be self-centered and eventually exhibit antisocial behavior. On the other hand, if their desire for relational affection or self-esteem is threatened, individuals exhibit pro-social behavior such as making charitable donations or helping others. According to Deci and Ryan (2000), self-determination motivates as a form of autonomous behavior. In particular, the level of social immersion and the level of satisfaction increase with autonomy, competence, and the maintenance of relationships, and when this is the case, people are more likely to emphasize the positive aspects of their exclusion . In other words, those who choose to exclude themselves will likely report more positive views than those who are excluded involuntarily. Therefore, the following hypotheses was proposed for Study 2.
$<\mathrm{H} 2>$ The effect of social exclusion on donation will be moderated depending on how the exclusion is understood by the excluded.

$<\mathrm{H} 2 \mathrm{a}>$ Those who understand themselves as selfexcluded will have higher donation intentions than those who understand themselves to be excluded for external reasons.

$<\mathrm{H} 2 \mathrm{~b}>$ Those who understand their exclusion to be uncontrolled will have higher donation intentions than those who understand their exclusion as controlled by others.

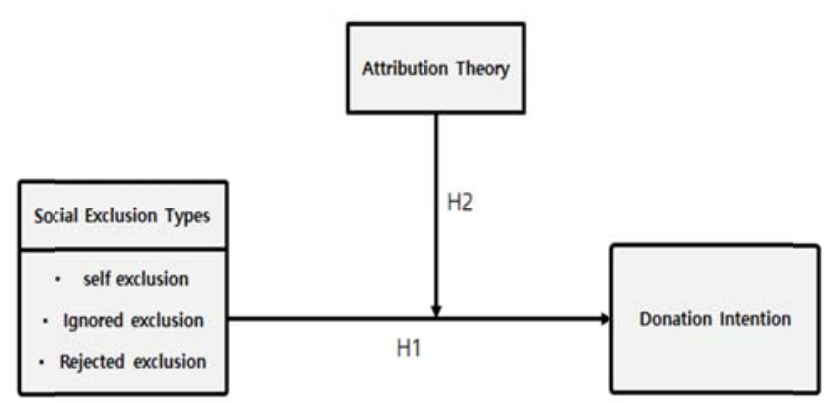

Figure 2. Research Model

The purpose of this study was to measure the degree of social exclusion through the Korean Social Exclusion Scale on socially weaker. A total of 230 questionnaires of the seniors aged 40 years or older were distributed and were collected from seniors aged 40 years or older, and we used 216 for final analysis.

Yun's (2012) social exclusion scale includes nine items involving consumption and assets, seven involving education, three involving health, five involving labor, six involving non-employment, four involving community facilities, and two involving self-governing domains. Using this scale, non-employed persons were selected for this study, and the questionnaire items were modified accordingly. The SPSS version 19 was used for the analysis and regression analysis. In their factor analysis of social exclusion, Nunnally and Bernstein (1994) showed that explanatory power was $78 \%$ in the six domains, and that Cronbach's alpha was greater than 7.0, as shown in Table 2. The internal consistency and reliability of the measurement items were secured. For internal consistency, dependent variables were the same items used in Study $1(\alpha=.902)$. 
Table 2. Factor Analysis of the Details of Social Exclusion

\begin{tabular}{|c|c|c|c|}
\hline Factor & Question Items & \begin{tabular}{|c|} 
Factor \\
Loadings
\end{tabular} & a \\
\hline \multirow{5}{*}{$\begin{array}{l}\text { Consumption } \\
\text { and assets }\end{array}$} & $\begin{array}{l}\text { I did not have enough money to } \\
\text { go out to see friends or go out }\end{array}$ & .897 & \multirow{5}{*}{.962} \\
\hline & $\begin{array}{l}\text { I have forgotten my favorite } \\
\text { hobby since I have difficulties in } \\
\text { life }\end{array}$ & .893 & \\
\hline & $\begin{array}{l}\text { It is a far story from me to go on } \\
\text { a vacation or holiday. }\end{array}$ & .871 & \\
\hline & $\begin{array}{l}\text { I could not enjoy the minimal } \\
\text { cultural life (movie, eating out, } \\
\text { etc.) because of lack of living } \\
\text { expenses. }\end{array}$ & .860 & \\
\hline & $\begin{array}{l}\text { I could not afford the clothes I } \\
\text { needed. }\end{array}$ & .829 & \\
\hline \multirow{4}{*}{$\begin{array}{l}\text { Community } \\
\text { facilities }\end{array}$} & $\begin{array}{l}\text { I do not have public institutions } \\
\text { (resident centers, etc.) that I can } \\
\text { use easily. }\end{array}$ & .831 & \multirow{4}{*}{.879} \\
\hline & $\begin{array}{l}\text { I do not have a social service } \\
\text { agency that is easy to use. }\end{array}$ & .828 & \\
\hline & $\begin{array}{l}\text { I do not have any convenient } \\
\text { cultural facilities (parks, libraries, } \\
\text { sports facilities). }\end{array}$ & .813 & \\
\hline & $\begin{array}{l}\text { I do not have any good medical } \\
\text { facilities (hospitals, pharmacies, } \\
\text { etc.) nearby. }\end{array}$ & .772 & \\
\hline \multirow{4}{*}{ Education } & I did not get enough education. & .837 & \multirow{4}{*}{.904} \\
\hline & $\begin{array}{l}\text { I have never been educated to } \\
\text { help with jobs }\end{array}$ & .820 & \\
\hline & $\begin{array}{l}\text { I could not get enough } \\
\text { educational opportunities } \\
\text { because of my family. }\end{array}$ & .749 & \\
\hline & $\begin{array}{l}\text { It is difficult to use computers or } \\
\text { modern communication devices } \\
\text { (mobile phones, etc.). }\end{array}$ & .740 & \\
\hline \multirow{3}{*}{ Health Labor } & $\begin{array}{l}\text { I have a disease that I should } \\
\text { always be careful about when I } \\
\text { am in my daily life. }\end{array}$ & .872 & \multirow{3}{*}{.924} \\
\hline & $\begin{array}{l}\text { A little better after treatment, but } \\
\text { I have a recurring disease. }\end{array}$ & .844 & \\
\hline & I am not healthy. & .814 & \\
\hline \multirow{4}{*}{ Labor } & $\begin{array}{l}\text { I will not work in the future even if } \\
\text { it is appropriate. }\end{array}$ & .771 & \multirow{4}{*}{.791} \\
\hline & $\begin{array}{l}\text { It is easy to relax even if I do not } \\
\text { receive the fair treatment }\end{array}$ & .770 & \\
\hline & I do not have the right job for me. & .714 & \\
\hline & $\begin{array}{l}\text { It is unlikely that society will } \\
\text { accept someone like me }\end{array}$ & .678 & \\
\hline \multirow[b]{2}{*}{ Self-governing } & $\begin{array}{l}\text { I do not know what the women's } \\
\text { association, the youth society, } \\
\text { and the neighborhood are doing }\end{array}$ & .858 & \multirow[b]{2}{*}{.722} \\
\hline & $\begin{array}{l}\text { I am not interested in the head of } \\
\text { a local government or a member } \\
\text { of a local governor (district } \\
\text { governor, district councilor, etc.). }\end{array}$ & .834 & \\
\hline
\end{tabular}

In order to examine the relationship between social exclusion and donation intention, the items of social exclusion were averaged together. The average value $(M=3.50)$ was recoded as 1 in the low group and 2 in the high group as a dummy variable. Multiple regression analysis was conducted by measuring donation intention as a dependent variable and by controlling demographic variables(sex and age were used as control variables). The results, shown in Table 3, found that groups with higher social exclusion levels had lower donation intentions $(\beta=-$ $.163, \mathrm{t}=-2.251, \mathrm{p}<.05)$. Therefore, as expected based on the findings in Study 1, social exclusion influences donations.

Table 3. Regression Analysis of Donation According to Level of Social Exclusion

\begin{tabular}{|c|c|c|c|c|c|}
\hline \multirow{2}{*}{} & & \multicolumn{2}{|c|}{ Step 1 } & \multicolumn{2}{c|}{ Step 2 } \\
\cline { 3 - 6 } & & $\boldsymbol{\beta}$ & $\mathbf{t}$ & $\boldsymbol{\beta}$ & $\mathbf{t}$ \\
\hline \multirow{2}{*}{ control } & sex & -.162 & $-2.266^{*}$ & -.167 & $-2.349^{*}$ \\
\cline { 2 - 6 } & age & -.039 & -.542 & -.002 & -.031 \\
\hline $\begin{array}{c}\text { Independent } \\
\text { variable }\end{array}$ & Social exclusion & & & -.163 & $-2.251^{*}$ \\
\hline & $\Delta \mathrm{R}^{2}$ & \multicolumn{2}{|c|}{.027} & \multicolumn{2}{|c|}{.052} \\
\hline & $\mathrm{F}$ & \multicolumn{2}{|c|}{2.629} & \multicolumn{2}{|c|}{3.479} \\
\hline
\end{tabular}

Note: ${ }^{*} \mathrm{P}<.05$, social exclusion level is dummy

To evaluate $\mathrm{H}_{2}$, we examined the relationship between attribution and social exclusion according to attributional focus, so a moderated regression analysis using mean centering was used (Table 4). The group with the lower mean value was re-coded as internal attribution 1 and the group with the higher mean was re-coded as external attribution 2, implying that donation intention increases when individuals perceive that they are the cause of their social exclusion $(\beta=.888, t=2.283, p<.05)$. As a result of the collinearity analysis, it was analyzed that the tolerance limits were all over 0.1 and the VIF (dispersion expansion factor) were all below 10 , so there was no collinearity problem. These results confirmed and supported the $\mathrm{H}_{2}$ and $\mathrm{H}_{2 a}$.

To verify $\mathrm{H}_{2 b}$, the following regression analysis was conducted using a control variable and uncontrollability as moderating variables, respectively. However, the results were statistically insignificant $(\beta=.179, t=.766, p>.05)$ and $\mathrm{H}_{2 b}$ was rejected.

Table 4. Moderation Effect of Attribution Focus

\begin{tabular}{|c|c|c|c|c|c|}
\hline & & \multicolumn{2}{|c|}{ Step 1} & \multicolumn{2}{|c|}{ Step 2} \\
\hline & & $\beta$ & $t$ & $\beta$ & $\mathbf{t}$ \\
\hline $\begin{array}{l}\text { Independent } \\
\text { variable }\end{array}$ & $\begin{array}{c}\text { Social exclusion } \\
\text { Level } \\
\text { focus }\end{array}$ & $\begin{array}{l}-.141 \\
-.062\end{array}$ & $\begin{array}{l}-1.994 \\
-.739\end{array}$ & $\begin{array}{l}-.614 \\
-.643\end{array}$ & $\begin{array}{l}-2.755^{* * * *} \\
-2.403^{* * *}\end{array}$ \\
\hline $\begin{array}{l}\text { Moderator } \\
\text { variable }\end{array}$ & $\begin{array}{l}\text { Social exclusion } \\
\text { Level * focus }\end{array}$ & & & .888 & $2.283^{* *}$ \\
\hline & $\Delta \mathrm{R}^{2}$ & \multicolumn{2}{|c|}{.018} & \multicolumn{2}{|c|}{.043} \\
\hline & $\mathrm{F}$ & \multicolumn{2}{|c|}{2.466} & \multicolumn{2}{|c|}{3.425} \\
\hline
\end{tabular}


The results of this study suggest that social exclusion affects donation intention, but even for individuals that perceive high social exclusion, donation intention is higher when they believe their exclusion is self-imposed.

\section{Conclusion}

Studies related to existing social exclusion did not provide consistent and clear evidence. However, it is clear that social exclusion has created a sense of discrimination and has been perceived as a psychological and a social downturn that does not actively engage in social activity such as donations or product purchasing behaviors. Faced with this fact, this study presented meaningful empirical findings related to social exclusion. In order words, the harmful effects of the social exclusion can be diminished depending on the types of social exclusion and attribution. The findings of the empirical analyses are as follows.

In study I, we measured and found that differences in donation intention varied according to type of social exclusion. Even among individuals that perceived the same level of social exclusion, individuals who perceived selfexclusion showed relatively higher donation intention than those who perceived by other-exclusion. Therefore, in order to reduce the negative effects even if the social exclusion is perceived, it is essential to develop a climate in which selfexclusion can be decided by self-exclusion rather than other-exclusion. In study 2, we measured donation intentions at the level of social exclusion (high vs. low) and found that the higher the perception of social exclusion, the lower the donation intention. However, it was confirmed that the group that perceived themselves as the cause of their exclusion (internal attribution) had a more positive donation intention.

Concerns about the exclusion of elderly people in Korea become more worrisome as the population ages. It is inevitable that elderly people will experience higher levels of exclusion, but it is possible to change their perceptions of this exclusion, to encourage them to see themselves as selfexcluded rather than other-excluded. Moreover, if they are excluded by rejecting rather than by ignoring, they will be able to participate in society later and eventually join the community and again participate in prosocial behavior. In order to overcome the limitations of the generalization of the result obtained by priming the social exclusion through the scenario in study 2 , the questionnaire was administered to actual elderly people.

Population aging in Korea is becoming a very serious social problem. In order to more accurately derive the issues of social exclusion of the elderly, experimental research (such as that conducted in Study 1) needs to be executed in tandem with practical examination of actual concerned populations - in this case, elderly individuals. Furthermore, it is expected that if research is extended to multicultural families, which are also considered socially weak groups that more robust research results will be derived.

The implications of this study are that the elderly are no longer beneficiaries of social protection but are important consumers who will lead a shared economy. That is, those who fall under the category of social underprivileged, in the marketing it is said that they has enough power to have high economic power and education level.

In spite of the social exclusion, marketing strategies that can induce pro-social behavior are necessary because of conflicting results (pro-social vs. anti-social). Among them, there is a method to induce voluntary exclusion or to search for the excluded cause have. For example, department stores display expensive products for their 40 s to $50 \mathrm{~s}$. The image of this brand is so expensive that young people are reluctant to approach and naturally become spaces for $40 \mathrm{~s}$ to $50 \mathrm{~s}$. It does not artificially create spaces for $40 \sim 50 \mathrm{~s}$, but a strategy that naturally does not participate young people to join in old people spaces is required.

\section{References}

Bandura, A. (1977). Social Learning Theory. New York: General Learning Press.

Baumeister, R. F., \& Leary, M. R. (1995). The need to belong: Desire for interpersonal attachments as a fundamental human motivation. Psychological Bulletin, 117(3), 497-529.

Baumeister, R. F., DeWall, C. N., Ciarocco, N. J., \& Twenge, J. M. (2005). Social exclusion impairs self-regulation. Journal of Personality and Social Psychology, 88(4), 589-604.

Buckley, K., Winkel, R., \& Leary, M. R. (2004). Reactions to acceptance and rejection: Effects of level and sequence of relational evaluation. Journal of Experimental Social Psychology, 40(1), 14-28.

Choi, N. H. (2016). Attribution of goal achievement to efforts and traits according to pride types and lay theory. Journal of Distribution Science, 14(2), 57-63.

Deci, E. L., \& Ryan, R. M. (2000). The "what" and "why" of goal pursuits: Human needs and the selfdetermination of behavior. Psychological Inquiry, 11(4), 227-279.

English, R. M. (1977). Correlates of stigma toward physically disabled persons. In R. Marinelli \& A. Dell Orto (Eds.), The Psychological and Social Impact of Physical Disability (pp.162-182). New York: Springer. 
Festinger, L. (1954). A theory of social comparison processes. Human Relations, 7(2), 117-140.

Fiske, S. T. (2004). Social Beings: A Core Motives Approach to Social Psychology. Hoboken, NJ: Wiley.

Folkes, V. S. (1988). Recent attribution research in consumer behavior: A review and new directions. Journal of Consumer Research, 14 (4), 548-565.

Gibbons, F. X., \& Buunk, B. P. (1999). Individual difference in social comparison orientation. Journal of Personality and Social Psychology, 76(1), 129-142.

Goffman, E. (1963). Stigma: Notes on Management of Spoiled Identity. Englewood Cliffs, NJ: Prentice-Hall.

Grenier, A. M., \& Gubereman, N. (2009). Creating and sustaining disadvantage: The relevance of a social exclusion framework. Health and Social Care in the Community, 17(2), 116-124.

Han, S. H., Cho, H. Y., \& Yang, H. C. (2014). Why do we pay for advertising models?: Suggestions for maximizing advertising effectiveness. East Asian Journal of Business Management, 4(1), 15-23.

Kim. J. O., Jung, M. L., \& Kim, M. J. (2014). The effect of food choice motive on attitude and purchase intention toward organic food. Journal of Distribution Science. 12(3), 17-24.

Kim, N. M., \& Youn, M. K. (2014). Global distribution enterprise's entry in the Chinese market: Focus on the three northeastern provinces. International Journal of Industrial Distribution \& Business, 5(3), 25-34.

Lee, H. K. (2009). A study of the effects of the elderly's social exclusion on their psychological well-being. Journal of Welfare for the Aged, 46, 315-336.

Lee, J., \& Shrum, L. J. (2011). Conspicuous consumption versus charitable behavior in response to social exclusion: A differential needs explanation. Journal of Consumer Research, 39(3), 1-17.

Lee, J. W. (2015). Antecedents of acceptance of social networking sites in retail franchise and restaurant business. Journal of Asian Finance, Economics and Business, 2(1), 29-36.

Levitas, R. (2006). The concept and measurement of social exclusion. In Pantazis, C., Gordon, D., \& Levitas, R. (Eds.), Poverty and Social Exclusion in Britain (pp. 123-160). Bristol: The Policy Press.

Link, B. G., \& Phelan, J. C. (2001). Conceptualizing stigma. Annual Review of Sociology, 27(1), 363-385.

Loveland, K. E., Smeesters, D., \& Mandel, N. (2010). Still preoccupied with 1995: The need to belong and preference for nostalgic products. Journal of Consumer Research, 37, 393-408.

Maner, J. K., DeWall, C. N., Baumeister, R. F., \& Schaller, M. (2007). Does social exclusion motivate interpersonal reconnection? Resolving the porcupine problem. Journal of Personality and Social Psychology, 92(1), 42-55.

Mead, N. L., Baumeister, R. F., Stillman, T. F., Rawn, C. D., \& Vohs, K. D. (2011). Social exclusion causes people to spend and consume strategically in the service of affiliation. Journal of Consumer Research, 13, 902-919.

Mizutani, F. (2016). The relationship between donor behavior and financial statements in Japan. Journal of Asian Finance, Economics and Business, 3(4), 3942.

Molden, D. C., Lucas, G. M., \& Gardner, W. L., Dean, K., and Knowles M. L. (2009). Motivations for prevention or promotion following social exclusion: Being rejected versus being ignored. Journal of Personality and Social Psychology, 96(2), 415-431.

Moon, J. Y. (2010). A cross-national study of social exclusion - with special reference to Korea and European countries. Korean Journal of Social Welfare, 62(2), 87-107.

Nunnally, J. C., \& Berstein, I. H. (1994). Psychometric Theory (3rd ed). New York: McGraw Hill.

Oh, M. J., \& Hwang, Y. Y. (2014). Does social exclusion decrease ethical consumption behavior. Journal of Consumer Studies, 25(4), 181-203.

Oh, M. J., Hwang, Y. Y., Quan, Z. X., \& Jung, J. C. (2014). The effect of three different generation types on prosocial consumption behavior. Journal of Industrial Distribution \& Business, 12(3), 55-63.

Oliver, R. L. (1997). Satisfaction: A Behavioral Perspective on the Consumer. New York: McGraw-Hill International Editions.

Piner, K. E., \& Kahle, L. R. (1984). Adapting to the stigmatizing label of mental illness: Foregone but not forgotten. Journal of Personality and Social Psychology, 47(4), 805-811.

Shim, C. H. (2004). Social exclusion and its policy perspective. Journal of Critical Social Welfare, 19, 13-54.

Song, J. H., Lee, N. G., Hwang, I. Y., \& Lee, S. W. (2015). The influence of verbal aggression on job involvement and turnover intention: The moderating effect of self-esteem. East Asian Journal of Business Management, 5(4), 19-28.

Statistics Korea (2015). Elderly People Statistics. Retrieved from http://kostat.go.kr/portal/korea/kor_nw/2/1/index. board?bmode=read\&aSeq=348565

Twenge, J. M., Baumeister, R. F., Tice, D. M., \& Stuke, T. S. (2001). If you can't join them, beat them: Effects of social exclusion on aggressive behavior. Journal of 
Personality and Social Psychology, 81(6), 10581069.

Warburton, W. A., Williams, K. D., \& Cairns, D. R. (2006). When ostracism leads to aggression: The moderating effects of control deprivation. Journal of Experimental Social Psychology, 42(2), 213-220.

Weiner, B. (1980). An Attributional Theory of Motivation and Emotion. New York: Springer-Verlag.
Williams, K. D., Cheung, C. K. T., \& Choi, W. (2000). Cyber ostracism: Effects of being ignored over the internet. Journal of Personality and Social Psychology, 79(5), 748-762.

Yun, S. H. (2012). Development of the Korean-type Social Exclusiveness Scale (KSES). The Korean Social Security Association, 28(1), 53-95. 